\title{
LEGO SEBAGAI PERMAINAN TRADISIONAL BERBASIS KELOMPOK PADA ANAK DOMINO (DISORDER OF GAMING AND INTERNET ADDICTION) : A SYSTEMATIC REVIEW
}

\author{
Fitrio Deviantony ${ }^{1}$, Purwita Lestari ${ }^{2}$, Anggalia $\mathbf{N}^{3}$, Wiwin Handayani ${ }^{4}$ \\ ${ }^{1}$ Fakultas Keperawatan Universitas Jember, Indonesia \\ 2,3,4Fakultas Keperawatan Universitas Jember, Indonesia \\ Email : fitrio.psik@unej.ac.id
}

\begin{abstract}
Game addiction is a pattern of behavior experienced by a person and results in indifference to other activities. The impact of game addiction can be prevented with traditional games that can help improve cognitive, social, and psychosocial. The aim of traditional game selection is to stimulate the brain to think critically and critically and to reduce the impact of games and the internet. To completed of this literature, the method used is a literature study specifically from 443,000 articles that fit the topic of 14 articles with vulnerable years from 2014-2019. From the results of the literature study it was found that one example of a traditional game is Lego. Lego can activate 9 benefits of traditional games including linguistic intelligence, mathematical logic intelligence, visual-spatial intelligence, musical intelligence, kinesthetic intelligence, natural intelligence, intrapersonal intelligence, intrapersonal intelligence, and spiritual intelligence. Other preventive measures can be done is to limit the duration of play, recognize the ins and outs of games in the game and the internet to be more vigilant and hold counseling for parents to activate or reintroduce traditional games that can help improve the basic abilities of children in all fields, especially in children 3-12 years, namely the growth and development phase is still ongoing. So that it can help the process of growth and development according to the child's period.
\end{abstract}

Keywords: Game Addiction, Legos, and Traditional Games.

\begin{abstract}
Abstrak : Kecanduan game merupakan pola perilaku yang dialami oleh seseorang dan mengakibatkan acuh terhadap aktivitas yang lain. Dampak dari kecanduan game dapat dicegah dengan permainan tradisional yang dapat membantu peningkatan kognitif, sosial, dan psikososial. Tujuan pemilihan permainan tradisional untuk merangsang otak berpikir kratif dan kritis serta mengurangi dampak game dan internet. Dalam menyusun metode yang digunakan adalah studi pustaka secara spesifik dari 443,000 artikel yang sesuai dengan topik sebanyak 14 artikel dengan rentan tahun dari 2014-2019. Dari hasil studi literatur didapatkan bahwa salah satu contoh permainan tradisional adalah lego. Lego dapat mengaktifkan 9 manfaat dari permainan tradisional diantaranya kecerdasan linguistik, kecerdasan logika matematika, kecerdasan visual-spasial , kecerdasan musikal, kecerdasan kinestetika, kecerdasan natural , kecerdasan intrapersonal, kecerdasan intrapersonal, dan kecerdasan spritual. Tindakan pencegahan yang lain bisa dilakukan adalah membatasi durasi bermain, mengenali seluk beluk permainan dalam game dan internet agar lebih waspada serta diadakannya konseling bagi orang tua untuk mengaktifkan atau memperkenalkan kembali tentang permainan tradisional yang dapat membantu meningkatkan kemampuan dasar anak di segala bidang terutama pada anak usia 3-12 tahun, yaitu fase tumbuh kembang masih berlangsung. Sehingga dapat membantu proses tumbuh kembang sesuai dengan periode anak.
\end{abstract}

Kata Kunci : Kecanduan game, Lego, dan Permainan Tradisional.

\section{PENDAHULUAN}

Era globalisasi merupakan bagian dari perkembangan zaman. Terdapat berbagai segi pada kehidupan manusia yang terpengaruh dengan adanya perkembangan zaman. Salah satu yang paling terlihat yaitu pudarnya permainan tradisional yang diakibatkan perkembangan dari permainan modern. Pada era ini, banyak golongan usia tidak terkecualikan anak-anak dan remaja lebih memilih permainan modern. Hal tersebut dikarenakan permainan modern yang jauh lebih asik dan menyenangkan, salah satunya adalah game online. Dalam penelitian (Ayenigbara, 2018) mengatakan bahwa terdapat hubungan antara kecanduan pada game online dan internet. Masalah yang diakibatkan apabila tidak ada kontrol diri terhadap game online akan menyebabkan kecanduan. Perubahan yang dapat dialami oleh pengguna game dan internet ialah perubahan kepribadian dan kontrol diri. Selain itu dampak lain adalah ansietas, deprsi, obesitas, gangguang pola 
tidur, dan stres. Hal ini dikarenakan pengguna game dan internet melakukan aktivitas yang bersifat sedentary lifestyle.

Dari survei the Asian Parent Insight pada tahun 2014, usai 3-8 tahun sebanyak $98 \%$ sudah bisa menggunakan gadget untuk bermain game. Hal ini disebabkan akses internet sangat mudah. Internet World States and Populations Statistic tahun 2017 mencatat pada 30 Juni 2016 bahwa Indonesia memasuki peringkat ke 5 pengguna internet. Jumlah pengguna internet Indonesia mencapai 132.700 .000 orang dengan tingkat $51,4 \%$ yang artinya internet merupakan bagian dari aktivitas sehari-hari termasuk anak-anak untuk mengakses yang digunakan bermain game. Apabila fenomena tersebut terus meningkat akan menyebabkan gangguan dalam bermain. Gangguan tersebut sudah diklasifikasi menjadi penyakit internasional (ICD-11), yaitu pola perilaku dalam permainan yang ditandai dengan gangguan kontrol atas permainan serta lebih memilih untuk bermain daripada melakukan kegiatan yang lain. Dalam melakukan pemantauan hal utama yang harus diperhatikan adalah pola perilaku yang memiliki keparahan seperti penrunan dungsi keluarga, sosial, pendidikan selama 12 bulan(WHO, 2018).

Kecanduan game dapat terjadi apabila terdapat pengaktifan pada otak, yang berhubungan dengan proses visual, pengelolaan perhatian, fungsi motorik, dan integrasi sensomotorik. Bagian yang terstimulasi adalah nucleus accumbens, amygdala, dan orbitofrontal cortex. Apabila intesintas dalam bermain meningkat maka hormon yang terdapat pada amygdala akan aktif dan mengeluarkan hormon tersebut saat pengguna game senang. Hormon yang dikeluarkan oleh amygdala adalah dopamin, yaitu bekerja saat perasaan senang. Sehingga mekanisme game yang dibuat untuk melepaskan dopamin dalam otak muncul apabila terdapat perasaan menyenangkan yang dapat membuat seseorang melupakan stres dan tekanan hidup (Lutfiawati, 2018).

Untuk mengurangi dampak dari game online dapat dilakukan pengaktifan kembali permainan tradisional. Permainan tradisional terdapat 9 manfaat yang dapat menstimulasi kecerdasan anak, yaitu kecerdasan linguistik (kemampuan berbahasa), kecerdasan logika matematika (kemampuan menghitung), kecerdasan visual-spasial (kemampuan ruang), kecerdasan musikal (kemampuan musik/ irama), kecerdasan kinestetika (kemampuan fisik baik motorik kasar dan halus), kecerdasan natural (keindahan alam), kecerdasan intrapersonal (kemampuan hubungan antar manusia), kecerdasan intrapersonal (kemampuan memahami diri sendiri), dan kecerdasan spritual (kemampuan mengenal dan mencintai ciptaan Tuhan) (Saputra, 2017).

\section{METODE PENELITIAN}

Dalam menyusun literature review
dilakukan pencarian menggunakan
beberapa database yaitu pubmed dan
google scholar untuk mencari artikel yang
relevan dengan topik. Kata kunci yang
digunakan dalam pencarian adalah game
addict and internet obsession, didapatkan
sebanyak 11 artikel dari pubmed dan
14.600 artikel dari google scholar. Dari kata
kunci tersebut diklasifikasikan lagi menjadi
game addict dan traditional game,
didapatkan sebanyak 30 artikel dari
pubmed dan 413.000 artikel dari google
scholar. Langkah selanjutnya adalah
melakukan pencarian secara spesifik yaitu
game addict dan advantage of lego yang
menggambarkan sesuai dengan topik.
Sehingga, sebanyak 14 artikel yang diterbitkan dari tahun 2014-2019 yang memiliki kualifikasi jurnal internasional terindeks scopus Q4-Q1, jurnal nasional terindeks sinta 1-3 dan merupakan original article dengan topik lego sebagai inovasi permainan tradisional dan game addict yang akan dianalisis secara komprehensif dan disusun menjadi literature review.

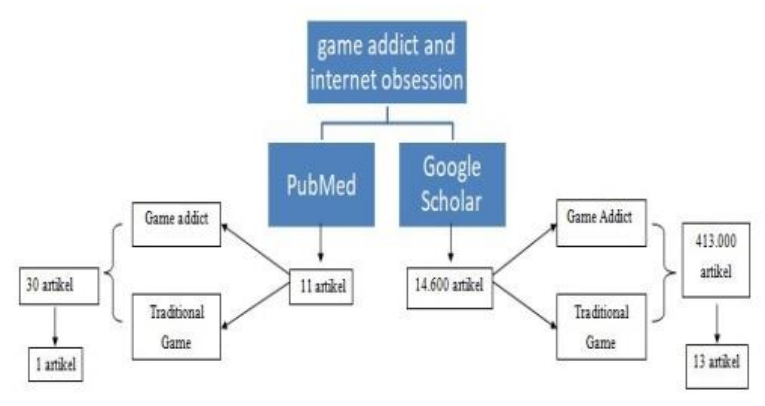




\section{HASIL PENELITIAN}

Table 1. Analysis Result

\begin{tabular}{|c|c|c|c|c|c|}
\hline No & Penulis & Judul & Tahun & Metode & Hasil \\
\hline 1. & $\begin{array}{l}\text { Toker, Sacip \& } \\
\text { Meltem H., B }\end{array}$ & $\begin{array}{l}\text { Antecedents } \\
\text { and } \\
\text { consequences } \\
\text { of game } \\
\text { addiction }\end{array}$ & 2016 & $\begin{array}{c}\text { Cross } \\
\text { sectional }\end{array}$ & $\begin{array}{l}\text { Dalam penelitian ini Toker } \\
\& \text { Meltem menyebutkan } \\
\text { bahwa gender, game } \\
\text { online, computer gaming, } \\
\text { grade point average, dan } \\
\text { self esteem dapat } \\
\text { meningkatkan game } \\
\text { addiction. Koefisien } \\
\text { korelasinya sebesar } 80 \% \text {, } \\
\text { artinya } 20 \% \text { lain dijelaskan } \\
\text { oleh factor yang tidak diteliti } \\
\text { pada penelitian ini (Toker, } \\
2016 \text { ). }\end{array}$ \\
\hline
\end{tabular}

\begin{tabular}{|c|c|c|c|c|}
\hline $\begin{array}{ll}2 . & \text { Euih, Y., N., } \\
\text { Inyoung C., } \\
\text { Tae,k-H., L., } \\
\text { Hyeseon L., Mi, } \\
\text { J., R., Hyun, C., } \\
\text { Dong, J., J And } \\
\text { Dai, J., K. }\end{array}$ & $\begin{array}{l}\text { The influence of } \\
\text { game genre on } \\
\text { Internet gaming } \\
\text { disorder }\end{array}$ & 2017 & $\begin{array}{c}\text { Cross } \\
\text { sectional }\end{array}$ & $\begin{array}{l}\text { Penelitian ini menyatakan } \\
\text { bahwa Internet Gaming } \\
\text { Disorder merupakan } \\
\text { diagnosis psikiati yang } \\
\text { disebabkan dari berbagai } \\
\text { genre game. Setiap } \\
\text { individu dengan IGD dalam } \\
\text { genre game memiliki } \\
\text { karakteristik yang berbeda, } \\
\text { yaitu pola gamenya (Na, E. } \\
\text { et all. 2017). }\end{array}$ \\
\hline
\end{tabular}
3. Lemmens, J., S., The Internet 2015 observational Internet gaming disorder and Patti, M., V Gaming Disorder Scale merupakan perilaku adiktif. Faktor-faktor yang mempengaruhi adalah kesepian, harga diri, kepuasan hidup, perilaku sosial dan agresi. Dalam penelitian ini dikatakan $63 \%$ terjadi pada laki-laki. Untuk melihat terjadinya Internet gaming disorder dapat dilakukan dengan menggunakan LCA (Lemmens, J., S \& Patti, M., V. 2015)

\begin{tabular}{|c|c|c|c|c|}
\hline $\begin{array}{ll}\text { 4. } & \text { Nofrans, E., S \& } \\
& \text { Yun, N., E. }\end{array}$ & $\begin{array}{l}\text { Permainan } \\
\text { Tradisional } \\
\text { Sebagai Upaya } \\
\text { Meningkatkan } \\
\text { Kemampuan } \\
\text { Dasar Anak }\end{array}$ & 2017 & $\begin{array}{l}\text { Cross } \\
\text { sectional }\end{array}$ & $\begin{array}{l}\text { Permainan tradisional } \\
\text { memiliki fungsi dalam } \\
\text { mengembangkan } \\
\text { keamampuan dasar anak. } \\
\text { Permainan tradisional } \\
\text { mudah dilakukan baik } \\
\text { dalam cara bermain, } \\
\text { maupun membuat alat } \\
\text { permainannya (Hibadullah } \\
\text { et al, 2018). }\end{array}$ \\
\hline
\end{tabular}




\begin{tabular}{|c|c|c|c|c|c|}
\hline No & Penulis & Judul & Tahun & Metode & Hasil \\
\hline 5. & $\begin{array}{l}\text { Drajat Edy } \\
\text { Kurniawan }\end{array}$ & $\begin{array}{l}\text { Pengaruh } \\
\text { Intensitas } \\
\text { Bermain Game } \\
\text { Online } \\
\text { Terhadap } \\
\text { Perilaku } \\
\text { Prokrastinasi } \\
\text { Akademik Pada } \\
\text { Mahasiswa } \\
\text { Bimbingan Dan } \\
\text { Konseling } \\
\text { Universitas Pgri } \\
\text { Yogyakarta }\end{array}$ & 2018 & $\begin{array}{c}\text { Pre } \\
\text { eksperimental }\end{array}$ & $\begin{array}{l}\text { Intensitas bermain game } \\
\text { online memiliki pengaruh } \\
\text { terhadap munculnya } \\
\text { perilaku prokrastinasi } \\
\text { akademik pada mahasiswa. } \\
\text { Hal tersebut dapat } \\
\text { ditunjukkan dengan } \\
\text { semakin tinggi intensitas } \\
\text { mahasiswa dalam bermain } \\
\text { game online maka semakin } \\
\text { tingi pula kecenderungan } \\
\text { mahasiswa untuk } \\
\text { berperilaku prokrastinasi } \\
\text { akademik (Kurniawan, } \\
\text { 2017). }\end{array}$ \\
\hline 6. & $\begin{array}{l}\text { Gandes } \\
\text { Nawangsari }\end{array}$ & $\begin{array}{l}\text { Traditional } \\
\text { Games } \\
\text { Intervention } \\
\text { Effectiveness for } \\
\text { Children } \\
\text { withInternet } \\
\text { Addiction }\end{array}$ & 2016 & $\begin{array}{l}\text { Pendekatan } \\
\text { eksperimental } \\
\text { dengan desain } \\
\text { pre-post } \\
\text { controlgroup }\end{array}$ & $\begin{array}{l}\text { Hasil penelitian } \\
\text { menunjukkan bahwa } \\
\text { permainan tradisional } \\
\text { cukup efektif sebagai } \\
\text { perawatan kecanduan } \\
\text { internet untuk anak-anak. } \\
\text { Permainan tradisional } \\
\text { diketahui membutuhkan } \\
\text { aktivitas fisik dengan teman } \\
\text { sebaaya dan permainannya } \\
\text { dapat digunakan sebagai } \\
\text { metode intervensi untuk } \\
\text { menangani kasus } \\
\text { kecanduan internet pada } \\
\text { anak-anak. Penjelasannya } \\
\text { adalah bahwa setelah } \\
\text { aktivitas fisik dengan teman } \\
\text { sebaya, tubuh mereka } \\
\text { melepaskan hormon } \\
\text { endorfin yang menciptakan } \\
\text { efek adiktif, akibatnya } \\
\text { mereka akan memilih untuk } \\
\text { melakukan aktivitas fisik } \\
\text { dengan teman sebaya } \\
\text { daripada bermain game di } \\
\text { gadget mereka } \\
\text { (Nawangsari, 2016) }\end{array}$ \\
\hline 7. & $\begin{array}{l}\text { Gisli } \\
\text { Thorsteinsson }\end{array}$ & $\begin{array}{l}\text { Designing Toys } \\
\text { to Support } \\
\text { Children's } \\
\text { Development }\end{array}$ & 2017 & $\begin{array}{l}\text { Wawancara } \\
\text { dan kuesioner } \\
\text { pada } 28 \\
\text { partisipan } \\
\text { yang berusia } \\
18-25 \text { tahun; } \\
\text { dengan } \\
\text { pandangan } \\
\text { retrospektif } \\
\text { mainan dan } \\
\text { pengaruh } \\
\text { terhadap gaya } \\
\text { hidup }\end{array}$ & $\begin{array}{l}\text { Hasil penelitian ini adalah } \\
\text { bahwa menggunakan } \\
\text { mainan di masa kanak- } \\
\text { kanak dapat memengaruhi } \\
\text { pengembangan } \\
\text { keterampilan utama dan } \\
\text { membentuk pandangan } \\
\text { anak pada masa kecil. } \\
\text { Lego dapat menciptakan } \\
\text { lingkungan sosial yang } \\
\text { menarik dan menantang } \\
\text { untuk anak-anak. Desain } \\
\text { produk yang dibuat } \\
\text { sederhana membuat ruang } \\
\text { untuk imajinasi dan } \\
\text { meningkatkan permainan } \\
\text { kreatif (Page \& } \\
\text { Thorsteinsson, 2017). }\end{array}$ \\
\hline
\end{tabular}


Fitrio Deviantony, Lego Sebagai Permainan...

\begin{tabular}{|c|c|c|c|c|c|}
\hline No & Penulis & Judul & Tahun & Metode & Hasil \\
\hline 8. & $\begin{array}{l}\text { Qiming Sun and } \\
\text { Pinata Winoto }\end{array}$ & $\begin{array}{l}\text { The Design of } \\
\text { an Intelligent } \\
\text { LEGO Tutoring } \\
\text { System for } \\
\text { Improving Social } \\
\text { Communication } \\
\text { Skills Among } \\
\text { Children with } \\
\text { Autism } \\
\text { Spectrum } \\
\text { Disorder }\end{array}$ & 2019 & $\begin{array}{l}\text { Tutoring } \\
\text { System }\end{array}$ & $\begin{array}{l}\text { Permainan tradisional Lego } \\
\text { dapat memberikan } \\
\text { panduan langkah demi } \\
\text { langkah untuk } \\
\text { menyelesaikan tugas yang } \\
\text { telah ditentukan } \\
\text { sebelumnya menggunakan } \\
\text { strategi dialog interaktif. } \\
\text { Lego memperkaya interaksi } \\
\text { antara anak-anak. Dalam } \\
\text { proses bermain, anak-anak } \\
\text { ditugaskan dengan } \\
\text { berbagai peran dan } \\
\text { diharapkan untuk } \\
\text { berkolaborasi membangun } \\
\text { struktur mengikuti } \\
\text { serangkaian instruksi jelas } \\
\text { yang diberikan. Anak-anak } \\
\text { dengan game dissorder } \\
\text { akan merasa lebih nyaman } \\
\text { dibandingkan dengan yang } \\
\text { bermain bebas, karena } \\
\text { akan lebih mudah memulai } \\
\text { komunikasi dengan teman } \\
\text { sebaya mereka (Sun \& } \\
\text { Winoto, 2019) }\end{array}$ \\
\hline
\end{tabular}

\section{Jeffrey $\mathrm{W} \mathrm{H}$ An Exploration}

MacCormack Mr, of a Communityan A. Matheson, Nancy L. Hutchinso
Based

LEGO®Social-

Skills Program

for Youth with

AutismSpectrum

Disorder

$\begin{array}{ll}2015 & \text { Wawancara } \\ & \text { orang tua dan } \\ & \text { penelian } \\ & \text { langsung pada } \\ \text { anak }\end{array}$

Hasil penelitian

menunjukkan lego dapat meningkatkan kolaborasi

anak dengan teman

sebayanya. Dalam

permainan lego terdapat tiga peran: insinyur , pembangun, dan pemasok. Hal ini dapat meningkatkan kolaborasi, perhatian bersama, komunikasi, dan menyelesaikan masalah. Permainan lego dapat mengatasi game dissoder pada anak karena anggota kelompok memiliki peran untuk bekerja sama dengan rekan-rekan mereka dalam menyelesaikan kegiatan. Kerja sama dalam permainan terstruktur setiap sesi memungkinkan anak merasa nyaman bekerja dengan rekanrekan mereka dan mengikuti aturan permainan (MacCormack et al, 2015). 


\begin{tabular}{|c|c|c|c|c|c|}
\hline No & Penulis & Judul & Tahun & Metode & Hasil \\
\hline 10. & $\begin{array}{l}\text { Stuart Flack, } \\
\text { Kevin Ponto, } \\
\text { Travis Tangen, } \\
\text { Karen B. Schloss }\end{array}$ & $\begin{array}{l}\text { LEGO as } \\
\text { Language for } \\
\text { Visual } \\
\text { Communication }\end{array}$ & 2019 & $\begin{array}{l}\text { data collection } \\
\text { and } \\
\text { visualization } \\
\text { will enable } \\
\text { new forms of } \\
\text { fact driven } \\
\text { community } \\
\text { based } \\
\text { advocacy. }\end{array}$ & $\begin{array}{l}\text { Lego dapat meningkatkan } \\
\text { kerjasama dan komunikasi } \\
\text { anak dengan teman } \\
\text { sebaya. Struktur lego tidak } \\
\text { hanya menyenangkan } \\
\text { untuk dibuat, tetapi juga } \\
\text { menyenangkan untuk } \\
\text { dilihat. Sehingga anak-anak } \\
\text { dengan game dissorders } \\
\text { merasa nyaman dalam } \\
\text { permainan dan dapat } \\
\text { mengalihkan } \\
\text { kecanduan. } \\
\text { Anak dapat memiliki seni } \\
\text { publik dan membaca pola } \\
\text { dalam data secara real } \\
\text { time, karena struktur } \\
\text { mudah dibangun. Sehingga } \\
\text { lego tidak memberikan rasa } \\
\text { bosan pada anak (Flack, } \\
\text { 2019). }\end{array}$ \\
\hline
\end{tabular}

\section{PEMBAHASAN}

Game addiction dapat menimbulkan gangguan psikis pada anak, karena dapat menimbulkan masalah sosial dan relasional. Game addiction menjadikan anak tidak mempunyai waktu bersama dengan keluarga dan teman sebayanya. Beberapa ahli di seluruh negara sepakat bahwa fenomena ini membutuhkan perhatian khusus seperti anak menarik diri dari rutinitas sosial, kecemasan dan prevalensi depresi yang meningkat pada anak-anak. Anak dengan game addiction umumnya kurang mampu berpartisipasi dalam permainan imajinatif yang kompleks. Sebagai contoh, sebuah kasus ditemukan di Korea Selatan di mana murid yang rajin tiba-tiba mengabaikan semua hal seperti makan dan beristirahat karena obsesinya terhadap permainan online. Oleh karena itu, intervensi untuk rehabilitasi dan pencegahan game addiction sangat diperlukan mengingat anak-anak masih dalam tahap perkembangan.

Berdasarkan hasil penelitian yang dilakukan oleh Fackler (2007) dan dikutip [10], permainan yang dilakukan berkelompok dengan teman sebaya dapat mengurangi kecenderungan game addiction di Korea. Penjelasannya adalah bahwa setelah bermain dengan teman sebaya, tubuh melepaskan hormon endorfin yang menciptakan efek adiktif, akibatnya anak- anak akan memilih untuk melakukan aktivitas fisik dengan teman sebaya daripada bermain game di gadget mereka. Berdasarkan penelitian ini permainan tradisional berbasis kelompok perlu dilakukan selama 2 bulan untuk mengatasi game addiction.

Permainan berbasis kelompok dalam mengatasi game addiction dapat dikemas melalui permainan tradisional, salah satunya adalah lego. Berdasarkan penelitian Gisli Thorsteinsson, lego terbukti dapat mengembangkan keterampilan anak baik secara mental, fisik, atau sosial, serta membentuk pandangan anak pada masa kecil. Desain lego yang sederhana dapat mengembangkan imajinasi dan pola pikir kreatif anak.

Menurut penelitian Sun, Q., \& Winoto, P. (2019) anak-anak dengan game addiction akan merasa lebih nyaman ketika bermain lego dibandingkan dengan bermain bebas, karena lego memungkinkan anak berkomunikasi dengan teman sebaya mereka. Dalam proses bermain lego, anakanak memiliki peran masing-masing dan diharapkan dapat berkolaborasi membangun struktur sesuai dengan instruksi yang diberikan. Desain permainan lego dapat menggunakan sistem ruang kelas kecil yang terdiri dari 8 hingga 10 siswa dan seorang guru pembimbing. Selama kegiatan, siswa akan dibagi menjadi 4 hingga 5 pasangan, dan masing- 
masing pasangan akan ditugaskan untuk membangun struktur lego secara kolaboratif sesuai dengan instruksi. Dalam permainan lego terdapat tiga peran: insinyur, pembangun, dan pemasok. Hal ini dapat meningkatkan kolaborasi, perhatian bersama, komunikasi, dan menyelesaikan masalah. Dalam permainan ini akan dievaluasi skema pembelajaran terkait waktu penyelesaian rata-rata, frekuensi kesalahan dan / atau kesalahan umum.

Metode permainan lego dapat meningkatkan kolaborasi serta interaksi sosial anak dengan teman sebaya. Kerja sama dalam permainan terstruktur setiap sesi memungkinkan anak merasa nyaman bekerjasama dengan teman mereka dan mengikuti aturan permainan. Dengan lego anak dengan game addiction akan dapat berkomunikasi dan meningkatkan kerjasama dengan teman sebaya.

\section{KESIMPULAN DAN SARAN}

Kecanduan game dan internet merupakan masalah yang serius sehingga membutuhkan perhatian dan penanganan segera, terkait dengan efek negatif yang ditimbulkan baik dari sisi psikologis maupun

\section{DAFTAR PUSTAKA}

Ayenigbara, I. O. (2018). Gaming Disorder and Effects of Gaming on Health : An Overview. Journal of Addiction Medicine and Therapeutic Science , 4 (1), 1-3.

Flack, S., Ponto, K., Tangen, T., \& Schloss, K. B. (2019). LEGO as Language for Visual Communication.

Hibadullah, C. F., ChePa, N., Bakar, N. A., \& Hussain, A. (2018). The Influence of Rewards on Perceptions, Competence, and Sensory and Imaginative Immersion of Malaysian Digital Traditional Games. International Journal of Engineering \& Technology, 7(3.20), 299-303

Kurniawan, D. E. (2017). Pengaruh Intensitas Bermain Game online Terhadap Perilaku Prokrastinasi Akademik Pada Mahasiswa Bimbingan Dan Konseling Universitas Pgri biologis. Seseorang yang mengalami kecanduan game dan internet dapat mempengaruhi kepribadian seperti rendahnya penilaian dan penghargaan diri, kemampuan berkomunikasi yang kurang baik, terbawa dalam permainan sehingga akan kesusahan dalam membedakan hal yang nyata dan dunia game. Jika perilaku terjadi secara berulang-ulang dan menjadi suatu kebiasan yang buruk, jalur dopaminergik di dalam otak akan menguat dan menetap sehingga menimbulkan kecanduan, yang akhirnya akan memperkuat sistem reaktif dan membuat sistem reflektif melemah sehingga kemampuan kognitifnya menurun dan sulit dalam mengendalikan kontrol dirinya.

Tindakan pencegahan yang bisa dilakukan adalah membatasi durasi bermain, mengenali seluk beluk permainan dalam game dan internet agar lebih waspada. Selain itu dapat mengaktifkan atau memperkenalkan kemballi tentang permainan tradisional yang dapat membantu meningkatkan kemampuan dasar anak, salah satunya bermain lego yang memiliki manfaat merangsang otak untuk berpikirnkritis dan kreatif.

\section{Yogyakarta. Jurnal} GUSJIGANG, 3(1).

Konseling

Lemmens, J., S \& Patti, M., V. 2015. The Internet Gaming Disorder Scale. American Psychological Association.

Lutfiawati, S. (2018). Memahami Kecanduan Game Online Melalui Pendekatan Neurobiologi. Journal Of Psychology , 1(1), 1-16.

MacCormack, J. W., Matheson, I. A., \& Hutchinson, N. L. (2015). An exploration of a community-based LEGO social-skills program for youth with autism spectrum disorder.

$\mathrm{Na}, \mathrm{E}$. et all. 2017. The Influence of game genre on internet gaming disorder. Journal of Behavioral Addictions (6) :2

Nawangsari, G. (2016). Traditional games intervention effectiveness for children with internet addiction. In Asean Conference 2nd psychology \& humanity (pp. 729-733). 
Page, T., \& Thorsteinsson, G. (2017). Designing Toys to Support Children's Development. Journal on Educational Psychology, 11(2), 1-10.

Saputra, E. N., \& Ekawati, Y. N. (2017). Permainan Tradisional Sebagai Upaya Meningkatkan Kemampuan Dasar Anak. Jurnal PSikologi Jambi , 2 (2), 48-54.

Sun, Q., \& Winoto, P. (2019, July). The Design of an Intelligent LEGO Tutoring System for Improving Social Communication Skills Among Children with Autism Spectrum Disorder. In International Conference on HumanComputer Interaction (pp. 172-181). Springer, Cham.

Toker, S \& Meltem, H., B. 2016. Antecedents and Consequences of Game Addiction. Computers in Human Behavior

World Health Organization. (2018). World Health Organization. [Diakses pada 8 September 2019]

https://www.who.int/features/qa/gamingdisorder/en/ 